J. Perinat. Med. 15 (1987) 21

\title{
Observations on the energy and redox state and protein synthetic rate in animal and human placentas
}

\author{
Michael J. Carroll and Maureen Young
}

Department of Gynecology, St. Thomas' Hospital Medical School, London, U.K.

\section{Introduction}

Dual perfusion of the isolated lobule of the human placenta is increasingly used for transport and metabolic studies: the method is relatively simple because only a portion of the large organ is used [24]. Assessment of the biological function of the preparation is most important for the trophoblast is known to have a high oxygen consumption [6] a high glucose utilization rate [23] and a high protein turnover rate in vivo [35] and might be expected to deteriorate quickly, suffering ischemic injury both during collection, and as a consequence of subsequent inadequate perfusion. CARROLL and Young [7] showed that tissue ATP values fall swiftly during ischemia, being halved in one minute in the guinea pig placenta, and BLOXAM and BOBINSKI (4] had similar findings for ATP, ATP/ADP ratios and energy charge in the human placenta after delivery. In contrast, PENFOLD et al. [22], Simmonds et al. [28] and IllsLey et al. [17] found little deterioration of the energy charge during 30 minutes after delivery and consider the human placenta a robust organ which does not deteriorate quickly. These investigators also considered that the tissue of the lobule dually perfused with oxygenated Krebs-Ringer solution, was stable for two to three hours, using the criteria of energy charge and oxygen and glucose consumption; further they observed little change in ultrastructure during this procedure [16]. CONTRACTOR et al. [8] however,

\section{Curriculum vitae}

Michael Carroll, $P h$. D., was born Luton U.K. in 1957 and graduated in biochemistry from the University of Bath in 1979. From 1979-1982 he studied at St. Thomas' Hospital Medical School, University of London for a PhD in Biochemistry investigating placental amino acid transfer and placental

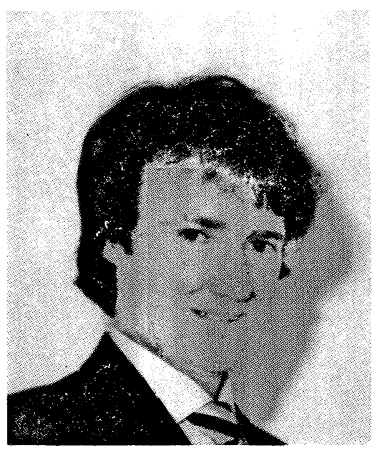
metabolism. 1982-1984 he worked as a research biochemist at Beecham Pharmaceuticals studying insulin secretion from the perfused pancreas. From 1984 he worked as a clinical research associate for Novo Laboratories in general diabetes research, and from early 1986 at Amersham International, involved in radiopharmaceutical research and development.

found cell swelling and vacuolation of the trophoblast after only one hour's open circuit perfusion with Earl's solution containing dextran, but little change in ultrastructure after two hours closed circuit perfusion using autologous fetal blood in the medium, confirming the beneficial effect of perfusing with blood, observed earlier by PANIGEL [21).

A third indicator of viability during perfusion, namely, mixed protein synthetic rate of the tissue has also been used by CARROLL and Young [7] and Young and SCHNEIDER [34]. 
Both perfused the intervillous space only, to minimize the delay in supplying the tissue with oxygen and nutrients after delivery; the latter oxygenated their medium in the usual way with $95 \% \mathrm{O}_{2}$ and $5 \% \mathrm{CO}_{2}$ whilst the former provided a more abundant supply with oxygenated red cells. Both groups found a lower turnover rate than is observed 'in vivo' in the pregnant ewe [36]. PALmer et al. [20) find that 'in vitro' techniques for protein turnover rate in skeletal muscle, give values which are one fifth those given by 'in vivo' methods, highlighting the difficulty in assuring the correct environment in isolated perfused tissues [12].

In this paper our preliminary observations are presented in full and extended to report the influence of the precursors of ATP, adenosine and inosine, on the energy and redox state of the human placenta and of its protein synthetic rate.

\section{Biological materials, methods and protocols}

\subsection{Guinea-pig-and-sheep placentas}

Guinea-pig placentas were studied in does, 55-62 days' pregnant (Duncan Hartley strain). The effect of ischemia was observed following cervical dislocation when the placentas were quickly sampled through a laparotomy and hysterotomy at approximately 15 second intervals for 2 minutes. The influence of nembutal anesthesia, $25-30 \mathrm{mg} / \mathrm{Kg}$, was also studied in the same way; samples were taken at less frequent intervals, approximately $20-30$ minutes for $1 \frac{1}{2}$ hours with as little disturbance as possible of the remaining fetuses and their placental circulations. $3-6$ placentas were taken from each animal. ATP and lactate concentrations were also measured in the cotyledons of sheep placentas sampled from pregnant Welsh mountain ewes at 135-145 days' gestation, under Chloralose, $(10 \mathrm{mg} / \mathrm{Kg})$ or Nembutal $10-20$ $\mathrm{mg} / \mathrm{Kg}$ anesthesia. The influence of ischemia was investigated by excising cotyledons and leaving them at room remperature when samples were taken approximately every 15 seconds for 2 minutes.

\subsection{Human placental lobule}

In order to measure the deterioration in the metabolite levels in the human placenta after delivery, the whole organ was placed on a plastic sheet on crushed ice within $1-3$ minutes of delivery and samples taken at intervals during one and a half hours.

The influence of perfusion for one hour was measured in lobules in which only the maternal intervillous space was perfused [36]; adjacent non-perfused samples were also taken at this time to measure the extent of the deterioration which occurs at $37^{\circ} \mathrm{C}$. The whole placenta, kept on crushed ice as before, was examined on the maternal surface for a discrete lobule. This was fitted, maternal side up, onto a plastic ring carrying six sturdy pins to pierce the tissue, and then cut away from the body of the placenta. The ring was fixed onto a plastic chamber $6 \mathrm{~cm}$ diamter, $4 \mathrm{~cm}$ high and approximately $120 \mathrm{ml}$ volume) and a second chamber of the same size was secured on top with wing nuts. The double chamber was placed, slightly tilted, in a saline bath at $37^{\circ} \mathrm{C}$, which served both to keep the tissue at a constant temperature and warm the perfused fluid in a coil; the latter was delivered from a stirred flask by a pulsatile pump at a rate of $0.5-1.0 \mathrm{ml} / \mathrm{min} / \mathrm{g}$. The perfusion was started by piercing the lobule centrally with pp100 tubing: this arterial inflow filled the intervillous space and expanded the basal plate; the venous outflow which emerged from the base of the lobule, was withdrawn continuously by a pulsatile pump from a small hole in the bottom of the chamber. This procedure was usually complete $10-15$ minutes after delivery; the lobule was perfused for 60 minutes.

The perfusion fluid contained electrolyte concentrations, as in Kreb's solution, $100 \mathrm{mg} \%$ glucose, and 6.5\% dextran (M.W. 40,000). Amino acids were added in concentrations equivalent to that found in human maternal plasma [33] and in some experiments with fetal plasma levels. ATP substrates were added in some experiments in an attempt to restore the depleted concentration resulting from the labor and the time taken to initiate the perfusion: 
adenosine, $1.0-50 \mu \mathrm{M}$ and inosine, $1.5 \mathrm{mM}$, were used.

Human red cells were always present in the perfusion fluid (final PCV $20-25 \%$ ). Heparinized blood from the polycythaemic clinic was stored overnight at $4{ }^{\circ} \mathrm{C}$ and the separated red cells were drained from the bottom of the plastic bag into the Kreb's mixture in a 2 litre conical flask. Physiological $\mathrm{p}_{2}$ levels were maintained by equilibration with $14 \% \mathrm{O}_{2}$ and $5 \% \mathrm{CO}_{2}$ in $\mathrm{N}_{2}$. Before the experiment the flask was used as a tonometer and rotated gently on its side so that a layer of blood was exposed to the gas. During the perfusion the red cells were kept in suspension with a magnetic stirrer, whilst a flow of the gas mixture was mantained in the space above.

The mixed protein synthetic rate was determined in the perfused lobule using the method of SENDER and GaRLICK [26]. The rate of uptake of a labelled amino acid was measured using U-C-L-lysine in the perfusion fluid; this lysine was added to the perfusate at a concentration of $0.05 \mathrm{Ci} / \mathrm{ml}$ to ensure sufficient counts in the placental protein for specific activity measurements. After an initial 20 minute perfusion period the label was added to the perfusate for a further 40 minutes; some lobular tissue was then freeze-clamped and extracted in $0.6 \mathrm{M}$ perchloric acid.

\subsection{Biochemical methods}

Perfusate $\mathrm{pH}$ and blood gas estimations were made using an 1L 413 analyzer.

The tissue samples were freeze-clamped with aluminium tongs cooled to the temperature of liquid nitrogen [30, 31]. 1-2 g tissue was pulverized to a fine powder under liquid nitrogen, dispersed in three volumes of $0.6 \mathrm{M}$ perchloric acid, and homogenized with a Silverson emulsifier on ice. After centrifuging and neutralizing the supernatant perchloric acid soluble extracts were analyzed for ATP, ADP, AMP, lactate and pyruvate by enzymic methods using the NADH $\rightleftarrows$ NAD reaction [3] using Boehringer kits (BCL, Lewes, East Sussex).
The initial treatment of the tissue for the protein synthetic rate estimations was the same as described for tissue metabolites but, after centrifuging, both the supernatant and protein pellets were retained for lysine assay and ${ }^{14} \mathrm{C}$ lysine measurement. The protein pellet was washed three times in perchloric acid and five times in acetone, and the dried powder hydrolyzed in Aristar hydrochloric acid at $120^{\circ} \mathrm{C}$ for 24 hours; the hydrolysate was evaporated to dryness and taken up in $0.09 \mathrm{M}$ hydrochloric acid and neutralized with $1.0 \mathrm{M}$ potassium hydroxide. The supernatants were also neutralized and the lysine concentration in both protein hydrolysate and supernatant assayed by the method of NaKatani, FujIOKa and Higashino [19]; the lysine is decarboxylated to cadaverine which is measured as a colored compound bound with dinitrofluoro-benzene. The specific activities of the ${ }^{14} \mathrm{C}$ sysine were determined using a modification of the method described by HutZler, OdieVre and Dancis [15]; lysine is again decarboxylated to cadaverine and the ${ }^{14} \mathrm{C}$ liberated, trapped on filter paper wicks soaked in Soluene (Packard Chemical Co), in sealed $25 \mathrm{ml}$ pyrex conical flasks. The wicks were transferred to $10 \mathrm{ml}$ Omnifluor (New England Nuclear) for ${ }^{14} \mathrm{C}$ counting in an Intertechnique SL 40 liquid scintillation spectrometer. Lysine decarboxylase was obtained from Sigma Chemical Co. (Poole, Dorset, UK).

\section{Results}

\subsection{The influence of nembutal and ischemia on placental metabolite concentrations}

The results are shown in figures $1 \mathrm{~A}$ and $\mathrm{B}$, $2 \mathrm{~A}$ and $\mathrm{B}$ and table I. The ATP and lactate concentrations in guinea pig placental tissue, taken immediately after nembutal anesthesia in the mother, were $1.16 \pm 0.05$ and $3.59 \pm 0.27$ S.E.M. mmol $\mathrm{Kg}^{-1}$ wet weight respectively $(\mathrm{n}=8)$. The ADP concentration was $0.26 \pm$ 0.02 , AMP $0.086 \pm 0.04$ and pyruvate 0.139 $\pm 0.005 \mathrm{mmol} \mathrm{Kg}^{-1}$ wet weight. The values for ATP and lactate did not change during two hours maternal anesthesia. Values similar to 


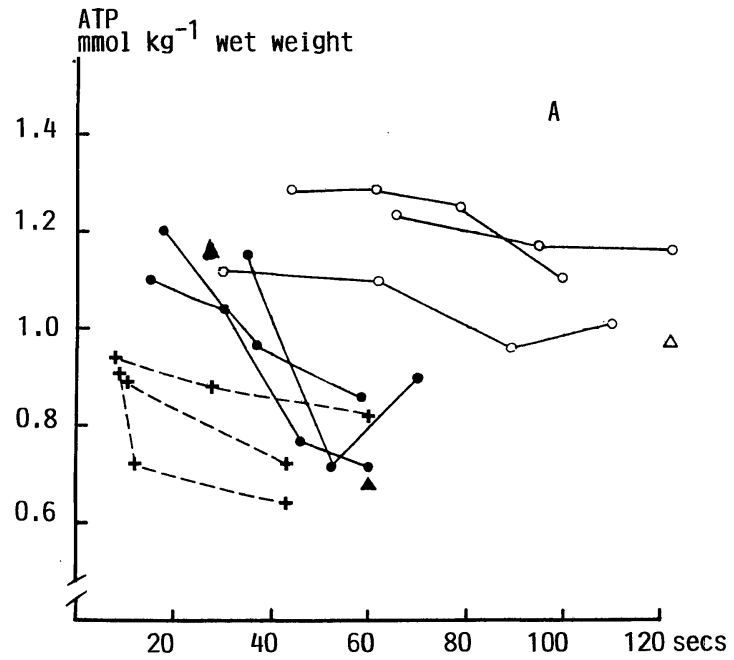

Figure 1. The influence of ischemia $(0)$ and nembutal anesthesia $(O)$ on guinea pig $(-)$ and sheep $(--+--)$ placental tissue in three individual experiments; also mean $(\Delta)$ from table I and $(\triangle)$ Carroll 1981.

A. depletion of ATP, B. accumulation of lactate; mmol $\mathrm{Kg}^{-1}$ wet weight.

\section{${ }_{\text {mmol }}^{\text {ATP }} \mathrm{kg}^{-1}$ wet weight}

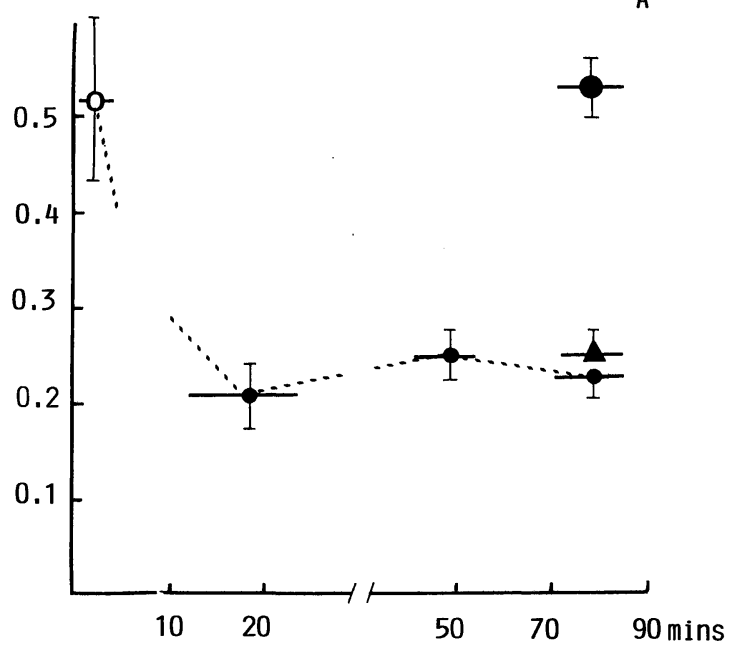

Figure 2. Influence of ischemia and perfusion on human placental tissue after delivery: $\mathrm{O}--$ at delivery $(\mathrm{n}=7) ;---\bullet--\mathrm{kept}$ at $4^{\circ} \mathrm{C}(\mathrm{n}=6) ; \bullet$ after 1 hour perfusion $(\mathrm{n}=10) ; \boldsymbol{\Delta}$ adjacent tissue at $37^{\circ} \mathrm{C}$ ( $\mathrm{n}=10)$.

A. depletion of ATP, B. accumulation of lactate; mmol $\mathrm{KG}^{-1}$ wet weight.
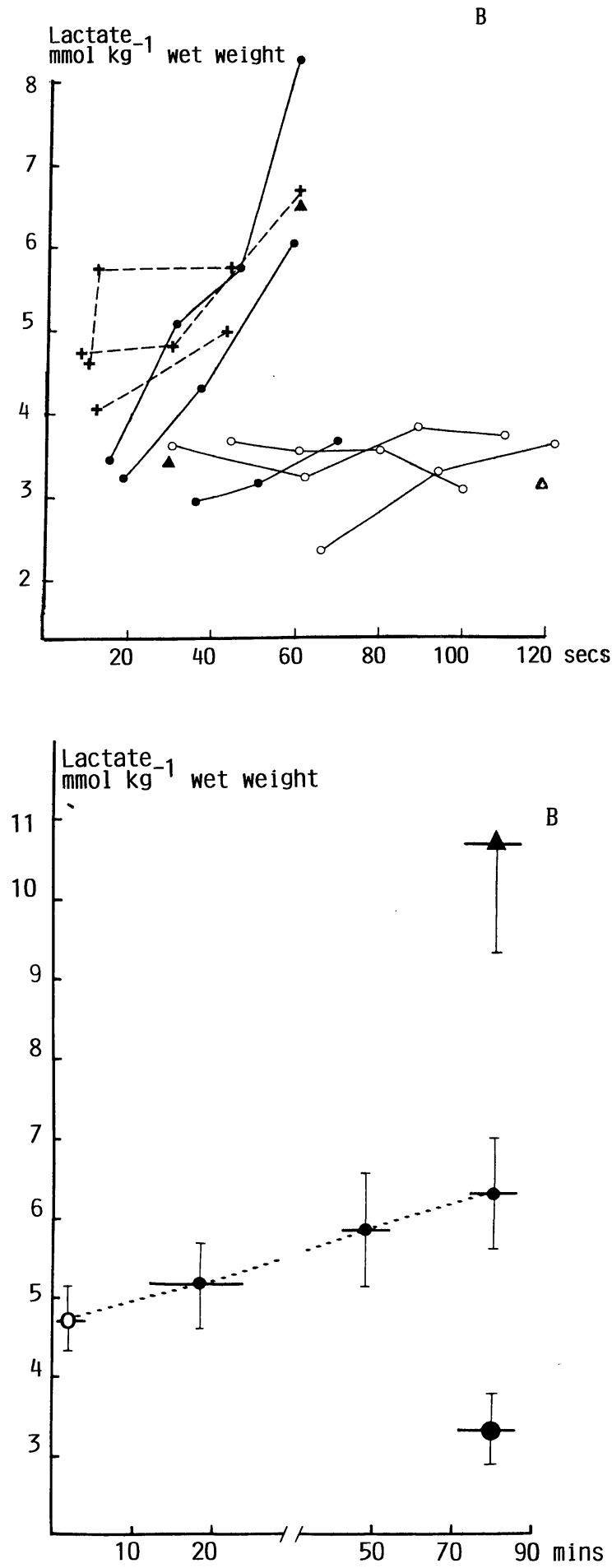

J. Perinat. Med. 15 (1987) 
Table I. The effect of ischemia, perfusion and adenylate precursors on the energy and redox state of placental tissue.

\begin{tabular}{|c|c|c|c|c|c|c|c|}
\hline & \multicolumn{7}{|c|}{ mmol Kg${ }^{-1}$ wet weight mean $( \pm \mathrm{SEM})$} \\
\hline & ATP & ADP & AMP & $\begin{array}{l}\text { Energy }{ }^{+} \\
\text {charge }\end{array}$ & Lactate & Pyruvate & $\begin{array}{l}\text { LAC/ } \\
\text { PYR } \\
\text { ratio }\end{array}$ \\
\hline $\begin{array}{l}\text { Guinea pig } \\
\text { Immediate freeze clamp } \\
(\mathrm{n}=8) \\
\text { Ischemia for } 30 \text { seconds } \\
(\mathrm{n}=6)\end{array}$ & $\begin{array}{l}1.16 \\
\pm 0.05 \\
0.69 \\
\pm 0.04\end{array}$ & $\begin{array}{l}0.26 \\
\pm 0.02 \\
-\end{array}$ & $\begin{array}{l}0.086 \\
\pm 0.04 \\
0.124 \\
\pm 0.08\end{array}$ & $\begin{array}{l}0.87 \\
\pm 0.08 \\
-\end{array}$ & $\begin{array}{l}3.59 \\
\pm 0.27 \\
6.64 \\
\pm 0.31\end{array}$ & $\begin{array}{l}0.139 \\
\pm 0.005 \\
0.140 \\
\pm 0.008\end{array}$ & $\begin{array}{l}25.8 \\
\pm 1.9 \\
46.1 \\
\pm 2.3\end{array}$ \\
\hline $\begin{array}{l}\text { Human } \\
\text { At delivery }(30 \text { seconds }-3 \text { minutes }) \\
(\mathrm{n}=7) \\
\text { Perfused for } 1 \mathrm{hr} \\
(\mathrm{n}=10) \\
\text { Paired ischemic placentae at } 37^{\circ} \mathrm{C} \\
(\mathrm{n}=10) \\
1.0 \mu \mathrm{M} \text { Adenosine in perfusion medium } \\
(\mathrm{n}=4) \\
50 \mu \mathrm{M} \text { Adenosine in perfusion medium } \\
(\mathrm{n}=4) \\
1.5 \mathrm{mM} \text { Inosine in perfusion medium } \\
(\mathrm{n}=4)\end{array}$ & $\begin{array}{l}0.52 \\
\pm 0.08 \\
0.53 \\
\pm 0.02 \\
0.25^{* *} \\
\pm 0.02 \\
0.84^{* * *} \\
\pm 0.10 \\
0.78^{* * *} \\
\pm 0.07 \\
0.54 \\
\pm 0.03\end{array}$ & $\begin{array}{l}0.21 \\
\pm 0.01 \\
0.16 \\
\pm 0.02 \\
0.27^{*} \\
\pm 0.02 \\
0.15 \\
\pm 0.06 \\
0.19 \\
\pm 0.07 \\
0.25 \\
\pm 0.03\end{array}$ & $\begin{array}{l}0.072 \\
\pm 0.013 \\
0.059 \\
\pm 0.009 \\
0.094 \\
\pm 0.017 \\
0.073 \\
\pm 0.006 \\
0.081 \\
\pm 0.006 \\
0.058 \\
\pm 0.002\end{array}$ & $\begin{array}{l}0.79 \\
\pm 0.02 \\
0.81 \\
\pm 0.02 \\
0.63^{* *} \\
\pm 0.03 \\
0.86 \\
\pm 0.04 \\
0.83 \\
\pm 0.05 \\
0.79 \\
\pm 0.03\end{array}$ & $\begin{array}{l}4.80 \\
\pm 0.30 \\
3.35 \\
\pm 0.40 \\
10.70^{*} \\
\pm 1.34 \\
3.67 \\
\pm 0.41 \\
3.55 \\
\pm 0.18 \\
1.61^{*} \\
\pm 0.12\end{array}$ & $\begin{array}{l}0.231 \\
\pm 0.011 \\
0.162 \\
\pm 0.014 \\
0.230 \\
\pm 0.040 \\
0.133 \\
\pm 0.010 \\
0.121 \\
\pm 0.090 \\
0.132 \\
\pm 0.010\end{array}$ & $\begin{array}{l}21.6 \\
\pm 1.6 \\
20.5 \\
\pm 2.2 \\
47.8^{*} \\
\pm 3.0 \\
28.4 \\
\pm 2.1 \\
29.5 \\
\pm 1.6 \\
12.2^{*} \\
\pm 1.2\end{array}$ \\
\hline
\end{tabular}

$* \mathrm{p}<0.05,{ }^{* *} \mathrm{p}<0.01, * * * \mathrm{p}<0.001$. Comparisons with placenta at delivery.

+ Energy charge $=\frac{\text { ATP }+0.5 \text { ADP }}{(\text { ATP }+ \text { ADP }+ \text { AMP })} ;[1]$

those with nembutal were observed for both ATP and lactate when placental samples were taken immediately after maternal cervical dislocation, but during the 60 seconds ensuing ischemia ATP levels fell to $0.70 \mathrm{mmol} \mathrm{Kg}^{-1}$ wet weight, and the lactate rose to $6.50 \mathrm{mmol} \mathrm{Kg} \mathrm{Kg}^{-1}$ wet weight; the concentration of AMP rose by $40 \%$ during this time. Ischemic sheep placental cotyledons showed a similar fall in ATP and rise in lactate concentration.

Figure $2 \mathrm{~A}$ shows that in the human placenta between 30 seconds and 3 minutes after delivery, the concentration of ATP was $0.52 \pm 0.08$ mmol Kg-1 wet weight $(\mathrm{n}=7)$ falling to 0.21 $\pm 0.03 \mathrm{mmol} \mathrm{Kg}{ }^{-1}(\mathrm{n}=10) 18$ minutes after delivery. No further changes were found after a further 80 minutes on ice. Lactate levels rose from an initial $4.8 \pm 0.3 \mathrm{mmol} \mathrm{Kg}^{-1}$ wet weight $(\mathrm{n}=7)$ to $6.4 \pm 0.6 \mathrm{mmol} \mathrm{Kg}^{-1}$ wet weight $(\mathrm{n}=10) 80$ minutes after delivery (figure $2 \mathrm{~B}$ ).
The concentrations of other metabolites immediately after delivery in $\mathrm{mmol} \mathrm{Kg}^{-1}$ wet weight, were ADP, $0.21 \pm 0.01$; AMP, $0.072 \pm 0.013$; and pyruvate, $0.231 \pm 0.011(\mathrm{n}=7)$, (table I). The energy charge was $0.79 \pm 0.02$, and the lactate/pyruvate ratio $21.6 \pm 1.6$. Ischemia reduced the energy charge to $0.63 \pm 0.03$, and raised the lactate pyruvate ratio to $47.8 \pm 3.0$.

\subsection{The influence of perfusion on tissue metab- olite concentration and protein turnover rate in the human placenta}

Figure $2 \mathrm{~A}$ shows that after a hour's perfusion, the concentration of ATP was similar to that in the immediate post-delivery period: the adjacent tissue, also kept at $37^{\circ} \mathrm{C}$ for one hour, had a low mean level of $0.25 \pm 0.02 \mathrm{mmol} \mathrm{Kg}^{-1}$ wet weight $(n=10)$, similar to that at $4{ }^{\circ} \mathrm{C}$. 
One hour's perfusion reduced the lactate level to $3.35 \pm 0.40 \mathrm{mmol} \mathrm{Kg}^{-1}$ wet weight $(\mathrm{n}=10)$, whilst in the adjacent non-perfused portion, the level had risen to $10.70 \pm 1.34 \mathrm{mmol} \mathrm{Kg}^{-1}$ wet weight (Figure $2 \mathrm{~B}$ ). Inspection of the individual washout profiles showed that the lactate which had accumulated during the ischemic period whilst the preparation was set up, was removed during the first $10-15$ minutes of perfusion; thereafter, the lactate production rate became constant at $0.38 \pm 0.04 \mathrm{mmol} \mathrm{Kg}^{-1} \mathrm{~min}^{-1}$ $(\mathrm{n}=10)$.

Protein synthetic rate was calculated from the specific activity of the protein bound lysine $\left(\mathrm{S}_{\mathrm{B}}\right)$ and the specific activity of the free intracellular pool $\left(\mathrm{S}_{\mathrm{i}}\right)$ according to the equation of SENDER and GARLICK [26]:

$$
\begin{aligned}
& \mathrm{S}_{\mathrm{B}} / \mathrm{S}_{\mathrm{i}}=\mathrm{vt} / \mathrm{Q} \\
& \mathrm{V}=\text { rate incorporation }{ }^{14} \mathrm{C} \text { lysine into protein } \\
& \left(\mathrm{mmol} \mathrm{day}{ }^{-1} \mathrm{~g}^{-1}\right) \\
& \mathrm{Q}=\text { amount of lysine in protein }\left(\mathrm{mmol} \mathrm{g}^{-1}\right) \\
& \mathrm{t}=\text { infusion time }
\end{aligned}
$$

The mean value for the bound lysine was $422 \pm$ $6 \mu \mathrm{mol} \mathrm{Kg}{ }^{-1}$ protein and the free intracellular, lysine $423 \pm 52 \mu \mathrm{mol} \mathrm{Kg}{ }^{-1}$ wet weight: the bound specific activity was $1.3 \times 10^{3}$ d. p.m. $\mu \mathrm{mol}^{-1}$ and the free $1.2 \times 10^{5} \mathrm{~d}$. p. m. $\mu \mathrm{mol}^{-1}$. The mixed protein synthetic rate was calculated to be $40 \pm 3 \%$ day $^{-1}$, corresponding to a half life of 1.78 days.

\subsection{The influence of adenosine nucleotide pre- cursors on tissue metabolite concentrations and protein turnover rate in the human placenta}

Table I shows that with $1.0 \mu \mathrm{M}$ adenosine in the perfusion medium the level of ATP in the placental tissue was $0.84( \pm 0.1) \mathrm{mmol} \mathrm{Kg}^{-1}$ at the end of the perfusion significantly higher than the value at delivery $(\mathrm{p}<0.001)$; but no difference in energy charge was observed: lactate and lactate/pyruvate ratio were not changed either, and the protein synthetic rate was $18 \pm 4 \%$ day $^{-1}$. Increasing the concentration of adenosine to $50 \mu \mathrm{M}$ in the perfusate had no further influence on either the energy or redox state of the tissue nor its mixed protein synthetic rate, $22 \pm 1 \% \mathrm{day}^{-1}$. The addition of $1.5 \mathrm{mM}$ inosine to the perfusion medium did not alter the energy state, but caused a marked fall to $1.61( \pm 0.12) \mathrm{mmol} \mathrm{Kg}^{-1}$ wet weight lactate and a reduction in the lactate/pyruvate ratio to $12.2( \pm 2.1)$ (table I). Lactate production rate fell to $0.13( \pm 0.04) \mathrm{mmol} \mathrm{min}^{-1} \mathrm{Kg}^{-1}$ ( $\mathrm{n}=4, \mathrm{p}=<0.05)$.

\section{Discussion}

The value of about $1.0 \mathrm{mmol} \mathrm{Kg}^{-1}$ wet weight ATP observed in the placental tissue from newly anesthetized or sacrificed animals is comparable with that found in the rat liver and kidney [13, 25] when account is taken of the large volume of blood in placental tissue, $60 \%$ $[5,10]$. Ischemia had an immediate effect in reducing the concentration of ATP in these placentas, as in the liver and kidney; the lower values $0.52 \mathrm{mmol} \mathrm{Kg}^{-1}$ obtained in the human placenta 30 seconds to 3 minutes after delivery indicated that the energy state had already been impaired by this time. BLOXAM and BABINSKI [4] found levels of ATP which were similar after vaginal deliveries and a little higher at cesarean section; their findings of a subsequent swift decline during ischemia are in agreement with our observations in animal placental tissue. The low value of $0.2 \mathrm{mmol} \mathrm{Kg}^{-1}$ wet weight maintained from 10 minutes onwards was found earlier by HOOVER and BARTHOLOMEW [14] and HAYASHI [11] who did not freeze clamp the tissue quickly, within seconds of delivery, to prevent metabolic changes continuing during its handling.

Perfusion of the placenta without adenylate precursors in the fluid partially restored the ATP concentrations, while a further but not complete, elevation could be obtained by immediate injection of the lobule to be perfused with cooled perfusion medium containing $1.0 \mu \mathrm{M}$ adenosine and maintaining this concentration during the perfusion period; any further increase in adenosine concentration provided no further protection against ATP degradation. 
No protection was achieved using inosine, which is known to be beneficial in the ischemic kidney [9].

The initial energy charge in both animal and human placentas was similar to that observed by PENFOLD et al. [22] and did not change markedly during ischemia as the latter observed. The use of the ATKINSON [1] equation for calculating energy charge may not be applicable to the placenta for the AMP concentration did not rise to the same extent as has been found in rat liver and kidney [13] and in brain [3]. This was also found by Young and SCHNEIDER [34] and may be explained by the particular pattern of adenosine metabolism in the placenta. Sim and MAGUIRE [27] found a high $5^{\prime}$ nucleotidase and adenylate kinase activity in the human organ but no adenylate deaminase activity and suggested that AMP degradation could only follow one route, namely, to adenosine; subsequently BARRADOs et al. [2] reported that human placental tissue could degrade ADP to adenosine without AMP accumulation. In the present study the most significant change in placental metabolite was the swift fall in ATP concentration and this would seem to be the most sensitive indication of deterioration in energy status as suggested by YOUNG and SCHNEIDER [34].

The fall in energy status was accompanied by the expected deterioration in cytosol redox state and a rise in tissue lactate concentration during ischemia. Perfusion lowered the tissue levels of lactate and restored the redox state of the cytosol to in vivo levels. Lactate production was lower than that observed by SCHNEIDER et al. [23] and Young and SCHNEIDER [34] and may be due to the perfusion of a more discrete area of tissue; WooDs and KREBS [32] found that inadequate perfusion of rat liver in vitro resulted in increased lactate production rates. Tissue lactate levels and production were reduced when the placental perfusion medium contained inosine and Strumia and STRUMia [29] have reported that inosine inhibits glycolysis in red blood cells.

It was considered that the measurement of mixed protein synthetic rate might be a good index of biochemical integrity as it is an overall measure of both structure and function in an organ. Using the specific activity of the intracellular free pool as the precursor in the calculation, a turnover rate of $40 \% \mathrm{day}^{-1}$ was found, two thirds of that observed in the sheep using the same precursor pool [35]. The addition of adenosine to the perfusion fluid apparently reduced the turnover rate to $20 \%$ in spite of the higher ATP level but this may be an artifact due to the higher specific activity found in the precursor pool for these placentas were perfused with amino acids of lower concentration, equal to that found in maternal plasma. However, this value is about twice that observed by Young and ScHNEIDER [34] and indicates that the extra oxygen supplied by the red cells was beneficial. A further benefit of using red cells may also be attributed to the small amount of human plasma proteins added with them which will help maintain the integrity of the cell membrane of the tissue [18] and its permeability.

\section{Summary}

The energy and redox states of placentas in newly anesthetized or sacrificed guinea pigs and sheep were compared with that of human placentas immediately after delivery. Subsequently the effect of ischemia was observed in both human and animal placentas. The influence of perfusion, using a fluid containing oxygenated red cells (adult human) was studied in the human placenta. Adenine nucleotide precursors were added to the perfusion fluid in an attempt to improve the energy and redox states and the mixed protein synthetic rate of the tissue.
The ATP and lactate concentrations in guine a pig placental tissue taken immediately after nembutal anesthesia were 1.16 and $3.59 \mathrm{mmol} \mathrm{kg}^{-1}$ wet weight respectively. One minute's ischemia caused a fall in ATP to 0.7 and a rise in lactate to $6.5 \mathrm{mmol} \mathrm{kg}{ }^{-1}$. The concentration of ATP in human placental tissue, 30 secs to 3 minutes after delivery of the organ, was 0.52 and of lactate $4.8 \mathrm{mmol} \mathrm{kg}^{-1}$ wet weight, suggesting that some biochemical deterioration had already occurred. A further fall in ATP to 0.21 and rise in lactate to $6.4 \mathrm{mmol}$ $\mathrm{kg}^{-1}$ wet weight took place during 20 mins of ischemia; 
thereafter the ATP level remained constant while the lactate continued to rise to $11 \mathrm{mmol} \mathrm{kg} \mathrm{m}^{-1}$ wet weight by $11 / 2$ hours. The initial energy charge was similar in both animal and human placentas, $0.8-0.9$, and was only reduced during prolonged hypoxia at $37^{\circ} \mathrm{C}$. Since the AMP did not rise to the same extent as in other tissues, it is suggested that the ATKINSON equation used in the calculation of energy charge may not be applicable to the placenta, and that the most sensitive indication of deterioration in energy status is the swift fall in ATP concentration.
Rapid establishment of maternal intervillous perfusion of an isolated lobule of the human placenta using ixygenated RBCS in the perfusion fluid, enabled the ATP and lactate levels to be maintained near to 'in vivo' values during one hour, with a protein turnover rate of $40 \%$ day $^{-1}$, two thirds of that observed 'in vivo' in the sheep. The addition of $1.0-50 \mu \mathrm{M}$ adenosine to the perfusion fluid improved the energy state of the tissue, but not its redox state nor protein synthetic rate. $1.5 \mu \mathrm{M}$ inosine in the perfusion medium did not alter the energy state but caused a marked reduction in lactate production.

Keywords: Animal, energy, human, placenta, proteinsynthesis, redox state.

\section{Zusammenfassung}

Untersuchungen zum Energie- und Redoxsystem sowie zur Proteinsynthese an Plazenten von Mensch bzw. Tier Wir haben das Energie- bzw. Redoxsystem bei Plazenten von frisch narkotisierten bzw. getöteten Meerschweinchen und Schafen mit dem von Plazenten beim Menschen unmittelbar nach der Entbindung verglichen. Die Auswirkungen der Ischämie waren sofort zu beobachten. Bei der Plazenta vom Menschen wurde der Einfluß der Perfusion mit einer Flüssigkeit, die oxygenierte Erythrozyten (von Erwachsenen) enthielt, untersucht. Der Flüssigkeit wurden Adeninnukleotid-Vorstufen zugesetzt, um das Energie- und Redoxsystem sowie die Proteinsyntheserate des Gewebes zu verbessern.

Die ATP- und Laktatkonzentrationen im Plazentagewebe von Meerschweinchen (unmittelbar nach Nembutalanästhesie entnommen) lagen bei 1.16 bzw. 3.59 $\mathrm{mmol} / \mathrm{kg}$ (Angabe immer pro $\mathrm{kg} \mathrm{Naßgewicht).} \mathrm{Eine}$ Ischämie über eine Minute führte zu einem Abfall des ATP auf 0.7 bzw. zu einem Laktatanstieg auf $6.5 \mathrm{mmol} /$ $\mathrm{kg}$. Die ATP-Konzentration in humanem Plazentagewebe betrug zwischen 30 Sekunden und 3 Minuten nach Geburt der Plazenta 0.52, die Laktatkonzentration $4.8 \mathrm{mmol} / \mathrm{kg}$; i. e. ein Hinweis darauf, daß einige biochemische Veränderungen bereits stattgefunden hatten. Eine Ischämie über 20 Minuten führte $\mathrm{zu}$ einem weiteren Abfall des ATP auf 0.21 und Anstieg des Laktats auf $6.4 \mathrm{mmol} / \mathrm{kg}$. Danach blieb der ATP-Spiegel konstant, während die Laktatkonzentration nach 1,5 Stunden bei $11 \mathrm{mmol} / \mathrm{kg}$ lag. Die initiale Energieausnutzung war bei Plazenten von Mensch und Tier vergleichbar $(0.8-0.9)$ und wurde nur durch länger anhaltende Hypoxien bei $37^{\circ} \mathrm{C}$ reduziert. Da das AMP nicht auf Werte, wie sie in anderen Geweben gefunden wurden, anstieg, glauben wir, daß die ATKINSON'sche Gleichung, mit der die Energieausnutzung berechnet wird, bei Plazentagewebe nicht angewendet werden kann; der empfindlichste Indikator für eine Verschlechterung im Energiesystem ist der rasche Abfall der ATP-Konzentration.

Wurde die Durchblutung der maternalen intervillösen Räume eines isolierten Lobulus aus der menschlichen Plazenta mit einer Flüssigkeit, die oxygenierte Erythrozyten enthielt, aufrechterhalten, lagen die ATP- und Laktatkonzentrationen über einen Zeitraum von einer Stunde im Bereich der ,in vivo'-Werte. Die ProteinTurnover-Rate betrug $40 \% / \mathrm{Tag}$, das sind $2 / 3$ der , in vivo'-Rate beim Schaf.

Nach Hinzufügen von 1.0-50 $\mu \mathrm{M}$ Adenosin zu der Perfusionsflüssigkeit konnte das Energiesystem des Gewebes verbessert werden, das Redoxsystem und die Proteinsyntheserate blieben jedoch unverändert. Eine Perfusionsflüssigkeit, der $1.5 \mu \mathrm{M}$ Inosin hinzugegügt wurde, veränderte den Energiehaushalt nicht, führte jedoch zu einer deutlichen Reduktion der Laktatproduktion.

Schlüsselwörter: Energie, Mensch, Plazenta, Proteinsynthese, Redoxsystem, Tier.

\section{Résumé}

\section{Observations de l'équilibre énergétique et redox et du taux de synthese protéique au niveaux de placentas ani- maux et humains}

On a comparé les états énergétiques et redox de placentas provenant de cochons d'Inde recemment anesthésiés ou sacrifiés et de moutons avec les états de placentas humains juste après l'accouchement. On a observé les effets de l'ischémie ultérieure au niveau des placentas humains et au niveau des placentas animaux. Sur le placenta humain, on a étudié l'influence d'une perfusion, utilisant un liquide contenant des hématies oxygénées (en provenance d'adultes humains). Des précurseurs des nucléotides à Adénine ont été ajoutés au liquide de perfusion dans l'optique d'apprécier les états énergétiques et redox ainsi que le taux de synthèse protéique par les tissus. $\mathrm{Au}$ niveau des fragments placentaires provenant des cochons d'Inde et prélevés immédiatement après anesthésie au membutal, les concentrations d'A. T. P. et 
de lactates sont respectivement de 1,16 et $5,59 \mathrm{mmol}$ $\mathrm{Kg}^{-1}$ en poids non sec. Les concentrations d'A. T. P. dans les fragments de placentas humains, 30 secondes à 3 minutes après la délivrance sont de 0,52 et ceux de lactates de $4,8 \mathrm{mmol} \mathrm{Kg}{ }^{-1}$ en poids non sec, ce qui suggère qu'il y a déjà une certaine détérioration biochimique.

Une chute plus importante d'A. T. P. à 0,21 et une élévation des lactates à $6,4 \mathrm{mmol} \mathrm{Kg}^{-1}$, de poids non sec survient au cours des 20 minutes d'ischémie; ensuite, le taux d'A.T.P. demeure constant tandis que les lactates continuent d'augmenter, jusqu'à $11 \mathrm{mmol} \mathrm{Kg}^{-1}$ de poids non sec en 1 heure et demie. La charge énergétique initiale est similaire dans les placentas animaux et humains, entre 0,8 et 0,9 , et elle ne diminue qu'au cours de l'hypoxie prolongée à $37^{\circ} \mathrm{C}$. Puisque l'A. M.P. ne s'élève pas de la même façon que dans les autres tissus, les auteurs suggèrent que l'équation d'AtKINSON, utilisée pour le calcul de la charge énergétique, n'est pas applica- ble au placenta et que l'indice le plus sensible de la détérioration de l'équilibre énergétique est la chute rapide de la concentration d'A. T.P.

La mise en place rapide d'une perfusion intervilleuse maternelle au niveau du lobule isolé d'un placenta humain, en utilisant dans le liquide de perfusion du R.B.C.S. oxygéné, est capable de maintenir les taux d'A.T.P. et de lactate pendant une heure, proches des taux trouvés in vivo, avec un taux de turn over protéique de $40 \%$ par jour, ce qui correspond au $2 / 3$ de ce qu'on observe in vivo chez la brebis.

Si l'on ajoute au liquide de perfusion $1,0-50 \mu \mathrm{M}$ d'Adénosine, on augmente l'équilibre énergétique du tissu, mais pas son équilibre redox ni son taux de synthèse protéique. L'apport dans la perfusion de 1,5 $\mu \mathrm{M}$ d'Inosine n'altère pas l'équilibre énergétique mais entraîne une diminution importante de la production de lactates.

Mots-clés: Animal, énergie, équilibre, humain, placenta, redox, synthèse protéique.

Acknowledgements: We wish to thank the Obstetric staff of St. Thomas's Hospital, especially the Sisters on the Labor Ward, for helping us obtain the placentas, the staff of the Blood Transfusion Unit for the blood from polycythemic patients and the Wellcome Trust and St. Thomas's Hospital Endowment Fund for supporting M. J. CARroll.

\section{References}

[1] AtKinson DE: The energy charge of the adenylate pool as a regulatory parameter. Interaction with feedback modifiers. Biochem J 7 (1968) 4030

[2] Barrados M, M KhokHER, R Hutton, IL Craft, P DANDONA: Adenosine diphosphate-degrading activity in placenta. Clin Sci 64 (1983) 239

[3] BergmeYer HV: Methods of Enzymatic Analysis, 2nd edition, p 1446 and 1464. Verlag Chemie, Weinheim, Academic Press, New York 1974

[4] Bloxam DC, PM BoBinsKr: Energy metabolism and glycolysis in the human placenta during ischaemia and in normal labour. Placenta 5 (1984) 381

[5] Bloxam DC, CF Tyler, M Young: Fetal glutamate as a possible precursor of placental glutamine in the guinea pig. Biochem J 198 (1981) 397

[6] Campbell AGM, GS Davies, JC MotT, AP FishMAN, HP HYMAN, GB JAMES: The oxygen consumption of the placenta and fetal membranes in the sheep. J Physiol 182 (1966) 439

[7] Carroll MJ, M Young: Mixed protein synthetic rate in the tissue of the isolated lobule of the human placenta. J Physiol 332 (1982) 5P

[8] Contractor SF, BM Eaton, JA Futin, KF BauMAN: A compensation of the effects of different perfusion regimes on the structure of the isolated human placental lobule. Cell Tissue Res 237 (1984) 609
[9] Fernando AR, JR Griffiths, EPN Donaghue, JP WARD, DMJ ARMSTRONG, WF HENDRY, D PERRET, JEA WICKHAM: Enhanced preservation of the ischaemic kidney with inosine. Lancet I (1976) 555

[10] Fuchs F: The red cell volume of the maternal and fetal vessels of the guinea pig placenta. Acta Physiol Scand 28 (1953) 162

[11] HAYASHI TT: Acid soluble nucleotides in human placenta and amino-chorionic membrane. Am J Obstet Gynecol 97 (1967) 1119

[12] HeARSE DJ: Detection and prevention of tissue injury during hypoxia and ischaemia. In: SCHNEIDER $\mathrm{H}$, J DANCIS (eds): In vitro perfusion of human placental tissue, p 48. Karger, Basel 1985

[13] Hems DA, JT Brosnan: Effects of ischaemia on content of metabolites in rat liver and kidney in vivo. Biochem J 120 (1970) 105

[14] Hoover CR, RA Bartholomev: Acid soluble nucleotides in placentae from normal and toxic patients. Obstet Gynecol 14 (1959) 309

[15] Hutzler R, P OdieVre, J Dancis: The determination of L-lysine in biological fluids. Anal Biochem 19 (1967) 529

[16] Illsley NP, H Fox, F van de Veery, L Chawner, P PENFOLD: Human placental ultrastructure after 'in vitro' dual perfusion. Placenta 6 (1985) 23 
[17] Illsley NP, JG Harmonde, P Penfold, SE Bardsley, SB CoAde, TE Stacey, FE Hytten: Mechanical and metabolic viability of a placental perfusion system 'in vitro' under oxygenated and anoxic conditions. Placenta 5 (1984) 213

[18] Michel CC, ME PhilliPs, MR TuRNER: The effects of native and modified bovine serum albumin on the permeability of frog mesenteric capillaries. J Physiol 360 (1985) 333

[19] Nakatani Y, M FujioKa, K Higashino: Enzymatic determinations of L-lysine in biological materials. Anal Biochem 49 (1972) 225

[20] Palmer RM, PJ Reeds, GE Lobley, RH Smith: The effect of intermittent changes in tension on protein and collagen synthesis in isolated rabbit muscles. Biochem J 198 (1981) 491

[21] PANigel M: Morphological evaluation of perfused tissues. In: Diczsfalusy E (ed): Karolinska symposia on research methods in reproductive physiology, 4th symposium, perfusion techniques, pp 74. Karolinska Institute, Stockholm 1971

[22] Penfold P, L Drury, RJ Simmonds, FE Hytten: Studies of a single placental cotyledon in vitro. I. The preparation and its viability. Placenta 2 (1981) 149

[23] Schneider H, JC Challier, J Dancis: Transport and metabolism of glucose and lactate in the human placenta studied by a perfusion in vitro. In: YounG, M, RDH Boyd, LD LONGo, G TELEGDY (eds): Placental Transfer Methods and Interpretations, pp 129. WB Saunders, Grinstead 1981

[24] SChNeIDER H, M Panigel, J Dancis: Transfer across the perfused human placenta of antipyrene, sodium and leucine. Am J Obstet Gynecol 114 (1972) 822

[25] SCHIMASSEK H: Metabolites of carbohydrate metabolism in isolated perfused rat liver. Biochem Z 336 (1963) 460

[26] SENDER PM, PJ GaRLICK: Synthesis rates of protein in the Langendorff-perfused rat heart in the presence and absence of insulin and in the working heart. Biochem J 132 (1973) 603
[27] Sim MK, MH Maguire: Presence of adenosine in human term placenta: determination of adenosine content and pathways of adenosine metabolism. Circ Res 31 (1972) 779

[28] Simmonds RJ, SB Coade, RA Harkness, L DruRy, FE HyTTEN: Nucleotide, nucleoside and purine base concentrations in human placentae. Placenta 3 (1982) 29

[29] Strumia MH, PV Strumia: The preservation of blood for transfusion. IX. The effect of increased $\mathrm{pH}$ and addition of inosine on red cell function. $\mathrm{J}$ Lab clin Med 70 (1972) 863

[30] Veech RL, RL Harris, D Velose, EH Veech: Freeze-Blowing: a new technique for the study of brain in vivo. J Neurochem 20 (1973) 183

[31] Wollenberger A, O Ristau, G Schoffa: Eine einfache Technik der extrem schnellen Abkühlung größerer Gewebestücke. Pflugers Arch 270 (1960) 399

[32] Woods HF, HA KrEBs: lactate production in the perfused rat liver. Biochem J 125 (1971) 129

[33] Young M, MA Prenton: Maternal and fetal plasma amino acid concentrations during gestation and in retarded fetal growth. Obstet Gynecol 76 (1969) 333

[34] Young MPA, H SchNeIDER: Metabolic integrity of the isolated perfused lobule of human placenta. Placenta 5 (1984) 95

[35] Young M, MDR STern, J Horn, DE NoAKes: Protein synthetic rate in sheep placenta in vivo; the influence of insulin. Placenta 3 (1982) 159

[36] Young MPA, M Young: A method for the rapid establishment of maternal intervillous space perfusion for metabolic studies in the isolated lobule of the human placenta. J Physiol 332 (1982) $4 \mathrm{P}$

Received October 21, 1985. Revised February 28, 1986. Accepted March 21, 1986.

Michael J. Carroll, Ph. D.

Amersham International, plc. Amersham Laboratories, White Lion Road, Amersham. Bucks. HP7.9LL. U.K. 